\title{
The Relationship between Corporate Governance Mechanisms and Going Concern Evaluation: Evidence from Firms Listed on Amman Stock Exchange
}

\author{
Bilal Nayef Zureigat, Faudziah Hanim Fadzil, Syed Soffian Syed Ismail \\ Othman Yeop Abdullah Graduate School of Business and School of Accountancy, Northern \\ University of Malaysia, Malaysia \\ Corresponding Email: deaa_sraheen@yahoo.com
}

Accepted: December 03, 2014

Doi:10.5296/ jpag.v4i4.6745 URL: http://dx.doi.org/10.5296/ jpag.v4i4.6745

\begin{abstract}
This study aims to examine the relationship between corporate governance mechanisms (representative by each of managerial, institutional ownership, board independence and board meeting) and going concern evaluation among Jordanian listed firms. Through using multiple regression analysis, the results of this study illustrates that there is a positive relationship between managerial ownership, board independence and board meeting and going-concern evaluation, while a negative relationship is found with institutional ownership. There are four main hypotheses, two of them which are managerial and institutional ownership are accepted, while board independence and board meeting are not supported. This study shed more light on the importance of complying with the requirements of governance code and instructions by the companies and the need to impose fines or sanctions on non-compliant companies. The results of this study contribute to the creditors' interest to be more alert to companies which may possess characteristics that contribute in manipulation of future companies.
\end{abstract}

Keywords: Going concern, Amman Stock Exchange, Board independence, Agency Theory 


\section{Introduction}

Going concern is defined traditionally as "an entity the is ordinarily viewed as continuing in business for the foreseeable future with neither the intention nor the necessity of liquidation, ceasing trading or seeking protection from creditors pursuant to laws or regulations" (Malaysian International Accounting, 2008). When the company faces any financial difficulties such as inability to fulfil its commitments and suffers losses, the external auditors' role becomes high importance in evaluating the ability of the company to continue. This will protect the interests of the financial statement users and help them to make their investments decisions. Ultimately, this could also protect the social and economic stability in Jordan. Furthermore, if the accountant does not provide the needed information, to the external auditor, definitely he will be unable to evaluate the companies' going concern and may not give the right decision to the investors.

According to the Companies Control Department (CCD) in Jordan, the statistics showed that from 2000 to 2011, there were 44 bankruptcy cases among Jordanian companies, where 26 companies $(59 \%)$ were from the industrial sector, 15 companies (34\%) from services sector and 3 companies (7\%) from the financial sector (http://www.ccd.gov.jo/2012). Globally, such bankruptcy cases which were attributed amongst other factors to the weak of governance practices (Iskandar, Rahmat, Noor, Saleh\& Ali, 2011).

In order to avoid any manipulation case in financial statements, the Jordanian government has issued a set of regulations and laws such as corporate governance code to insure the credibility of financial statements. Accordingly, the companies listed at Amman Stock Exchange (ASE) should form boards and committees to be committed with the requirements of corporate governance code. In 2002, the Securities Law in Jordan forced the public companies to apply corporate governance rules to enhance the transparency and accountability of financial statements. After the financial crises in 2008, the Jordan Securities Commission has issued a revised code of Corporate Governance for listed firmson ASE in order to determine the responsibilities and duties of boards and committees in public companies.

The separation between managers and shareholders of firms leads to conflicts of interests. This isbecause the corporate managers control firms' assets effectively but in general they do not have a large number of the shares in their firms (Berle\& Means, 1932; Jensen \&Meckling, 1976). Due to these conflicts, major companies such as Enron and WorldCom have collapsed (Habash, 2010). Such conflicts cannot be completely resolved bycontracts becauseit is costly and difficult to write and impose complete contracts (Fama \& Jensen, 1983; Hart, 1995). Thus, under the incomplete contracts' world, mechanisms of corporate governance have arisen to limit such conflicts and to assist the firm to protect their investments to ensure continuity. Mechanisms of Corporate governance (such as ownership structure, board of directors etc) vary in terms of the costs and benefits. In this study, the collection of governance mechanisms is collected to assist the firms in their continuity by limiting the conflicts between corporate managers and shareholders. Such mechanisms are likely to vary across firms systematically because such costs and benefits are more likely to differ based on attributes of firm (Leftwich, Watts \& Zimmerman, 1981; Agrawal \& Knoeber, 1996; Boone, Field, Karpoff, \& Rahega, 2006; Watts, 2006).

\section{Literature Review and Hypotheses Development}

This study shows through this section the previous relevant studies and also develops also the research hypotheses. Four main hypotheses test the relationship between managerial and institutional ownership and board independence and board meeting with going concern evaluation. These relationships are shown below:

\subsection{The association between managerial and institutional ownership and going concern evaluation.}

Past studies on the effects of management ownership on the firm performance have shown 
inconsistent results. For example, Davidson, Jiraporn, Kim, \& Nemec (2004) found non-linear relationship for companies involving initial public offerings in Thailand. They observe positive significant associationamong managerial ownership and earnings before interest and tax when the ownership is low or high. They also found negative associationamong managerial ownership and firm performance. Parker, Peters \& Turetsky, 2005) suggested that equity ownership by the management and external mechanisms respectively improve the company's financial performance.

In contrast, previous studies also showed that management equity ownership has a significant positive relationship with firm value and agency cost (Iskandar et al., 2011). Other study reports non-linear relationships whereby at a certain level of management ownership reduces agency costs but at another level, it increases the agency costs (Davidson et al., 2004). Based on the agency theory, it is expected that management equity ownership has a significant negative relationship with going concern problem. When a manager becomes part of the company owners, they will have the same amount of incentive as that of the owner. Such a manager will not take risks that will not benefit them. It is therefore expected that the higher the level of management ownership in the company, the lower is the level of conflict of interest. This would in turn increase the performance of the company and avoid companies from facing going concern (Gul, Atalay \& Hanninen, 2003).

Parker et al (2005) found that managerial ownership is inversely associated with repeated going concern modifications. Iskandar et al (2011) also found that the management equity ownership has a negative significant relationship with going concern. Thus, these findings support the agency theory which argues that the best practice of corporate governance helps companies avoid financial and operational problems. Thus, the first research hypothesis is suggested as follows:

\section{H1: There is a negative relationship between managerial ownership and going concern evaluation.}

As for institutional ownership, earlier findings were consistent with Bhattacharya and Graham (2007) in the contention that institutional ownership stakes negatively impact performance. They also revealed that firm performance does not influence pressure-resistant institutional ownership stakes; a result consistent with other studies in literature such as Demsetz and Villalonga (2001) and Thomsen, Betke, Glahn and Piper (2006), which contended that ownership decisions do not vary with firm performance.

Clay (2001) and Iskandar et al. (2011) found a positive impact of institutional investment where institutional investors are able to act more effectively to the management compared to individual investors. Institutional investors have more incentives to monitor the management because the value of their investments is larger. Ahmad (2008) also showed that the institutional investors have more expertise to implement the monitoring responsibility at the lower costs (Gilson \& Kraakman, 1991).

In the relationship between institutional ownership and going-concern, to the knowledge of the researcher, there is lack of studies that are carried out in this context (Iskandar et al., 2011). Parker, Peters and Turetsky (2005) examined such relationship and their results suggest that equity ownerships by the management and institutional investors from internal and external mechanisms respectively to improve the company's financial performance. Iskandar et al. (2011) found that the institutional investor equity ownership respectively has negative significant relationships with going concern. These findings support the agency theory which argues that the best practice of corporate governance helps companies avoid financial and operational problems. In the meantime, institutional investors become as external monitors other than the auditors.

Based on the agency theory and the results that discussed above, it is predicted that there is a negative relationamonginstitutional ownership and going concern evaluation. Thus, this study presents the second hypothesis as follows: 
H2: There is a negative relationship between the institutional ownership and going concern evaluation.

\subsection{The association between board independence and meeting and going concern evaluation}

Independence of board of directors and equity ownership have been widely researched in the context of company performance in many of developed countries such as U.S, U.K, Australia, Canada and Belgium (Iskandar et al., 2011). Independence of board members is often referred in terms of independence members of board of directors and its leadership structure. However, results of the studies have been inconsistent. For instant, independence of board of directors is often associated with the composition of non-executive directors which is also referred to as external directors. Previous studies in this area have shown mixed results. Some studies show positive relationships between the existence of external directors and the company's performance (e.g. Alexander, Veerle \& Hubert, 2001; Elloumi \& Gueyie, 2001) while others show no such significant relationships (Fosberg, 1998; Iskandar et al., 2011). In contrast, Parker, Peters and Turetsky (2005) found that board independence is inversely associated with going concern modifications.

The study provides evidence that independent external directors have better ability to monitor and control the management relating to specific contexts such as company takeover, financial performance and financial reporting (Iskandar et al., 2011). The appointment of independent board members is the main criteria to make sure that the effectiveness of the boards. Boards of directors with independent external directors as members would be able to avoid any conflict of interest and to monitor the management effectively (Abdullah, 2001). Perry and Shiv (2005) finds that boards comprised of outsiders are more likely to make proactive efforts intended to curb downward performance trends.

Parng and $\mathrm{Fu}$ (2011) detected firms with going-concern risk is precisely critical to all financial professionals. Based on the above argument, it is assumed that the existence of independent directors has a positive influence on the company performance in reducing the company going concern (Iskandar et al., 2011). Therefore, this study suggests the following hypothesis:

H3: There is a positive relationship between the board independence and going concern evaluation.

Regarding to the board meeting, boards of directors that frequently have meetings are more likely to conduct their responsibilities according to the interests of their shareholders, because ample time can be more dedicated to control and monitor issues such as conflicts of interest, monitoring management and earnings management. In addition, those that have fewer meetings do not have time to examine complex issues and spend their time in managing plans (Abed, Al-Attar, \& Suwaidan, 2012). To the best of the researcher's knowledge, only few studies were dedicate to the effect of board meeting frequency on going concern. Based on Xie, Davidson, and DaDalt (2003) findings, a board that does not meet frequently only has time to sign off management plans and conduct presentations and hence the directors may not have enough time to dedicate on corporate issues like earnings'manipulation. The sample of their study was 282 firm and they concluded that managing the earnings is significantly and negatively affects the frequency of board meeting. In a related study, Chen, Miller, Francis, and Russell (2011) demonstrated that board meeting does not moderate the negative impact of concentrated owners on the performance of the firm.

Xie et al. (2003) found a negative and significant association amongearnings management and the number of board meetings. Conversely, Uzun, Szewczyk, and Varma (2004) found that there are no differences in the frequency of board meeting among firms that practiced fraud and other healthy firms.

Holistically, board meetings are deemed as an indication for boards' diligence. Many 
previous researches have assessed the effects of board meetings by taking into account the number of meetings or regularity (Vafeas, 1999; Beasley, Carcello, Hermanson, \& Lapides, 2000; Carcello, Hermanson \& Neal, 2002). This study employs the same method and techniques to gauge the yearly number for board meetings. Thus, this study presents the following hypothesis:

H4: There is a negative relationship between board meeting and going concern evaluation.

\section{Methodology}

\subsection{Research Sample and Data}

This study uses only industry and service sector for companies listed on ASE. This is because there are more companies suffered from bankruptcy in these sectors. There were 44 bankruptcy cases among Jordanian companies from 2000 to 2011. 26 companies (59\%) were from the industrial sector, 15 companies (34\%) from services sector and only 3 companies (7\%) from the financial sector (http://www.ccd.gov.jo/2012). This study uses data for year 2011. The final sample was 113 firms. Companies in the financial sector were excluded because they have different Code of Corporate Governance issued by the Insurance Commission and Central Bank of Jordan (Al-Akra, Ali \& Marashdeh, 2009). Thus, the industrial and services sector are more suitable to test the relationship between corporate governance and going concern evaluation in Jordan.

\subsection{Variables and Measurements}

Managerial Ownership: managerial ownership was calculated by dividing the total number of firm's shares owned by the board members and top management on the total number of firm's shares (Habbash, 2010).

Institutional Ownership: institutional ownership was calculated by dividing the number of shares owned by institutions to total number of firm's shares (Al-Fayoumi, Abuzayed \& Alexander, 2010).

Board Independence: board independence was measured by the percentage of non-executive directors to total board members (Habbash, 2010).

Board Meeting: board meeting is calculated as the total number of board meetings held in a year (Habbash, 2010).

Going Concern: Altman Model (1968) is adopted to evaluate the going concern of firms which is deemed as one of the financial ratio that have high accuracy level reached to $90 \%$ in evaluating the going-concern of firms. Hence, this study employs five of Altman's ratios to determine the $\mathrm{Z}$ score;

$Z$ Score $=1.2 \frac{W C}{T A}+1.4 \frac{R E}{T A}+3.3 \frac{E B I T}{T A}+0.6 \frac{M V}{B V}+1.0 \frac{S A}{T A}$

Where

$$
\begin{aligned}
& \mathrm{Z} \text { score } \quad \text { Firms' financial condition (strong, moderate and weak) } \\
& \text { WC/TA }=\text { Working capital } \div \text { total asset } \\
& \text { RE/TA }=\text { Retained earnings } \div \text { total asset }
\end{aligned}
$$




$$
\begin{aligned}
& \text { EBIT/TA }=\text { Earnings before interest and tax } \div \text { total asset } \\
& \text { MV/TA }=\text { Market value of share } \div \text { book value of debt } \\
& \text { SA/TA }=\text { Sales } \div \text { total asset }
\end{aligned}
$$

Based on the percentage of $\mathrm{Z}$ score, Altman has dividedthe companies into strong, moderate and weak. In detail, strong level if $\mathrm{Z}$ rate is $>2.99$, moderate level when $\mathrm{Z}$ rate is between 1.811 and 2.98, while the weak level when $\mathrm{Z}$ rate is $<1.811$. Therefore, this study uses the following regression model to examine the relationship between managerial and institutional ownership, board independence and board meeting:

$$
\text { ZScore }=\beta_{0}+\beta_{1} \text { MANOW }_{i t}+\beta_{2} \text { INSTOW }_{i t}+\beta_{3} \text { BIND }_{i t}+\beta_{4} \text { BMEET }_{i t}+\varepsilon_{i t}
$$

Where:

Z Score = Firms' financial condition (strong, moderate and weak)

MANOW = Managerial ownership was calculated by the percentage of shares held by directors on the board to the total number of firm's shares.

INSTOW = Institutional ownership measured by the natural logarithm of the number of shares owned by institutional investors.

BIND = Board independence was measured by the percentage of non executive directors on the board to the total number of board members.

BMEET = Board meeting refers to the number of board meetings held annually by the board of directors.

\section{Finding}

\subsection{Descriptive Analysis}

As presented in Table 1, the mean value of going concern is $73.19 \%$. This ratio refers to almost $73 \%$ of Jordanian firms received audit report with going concern. The mean value of managerial ownership is $48.7 \%$, whereas the minimum value is $11 \%$. This refers that $43.2 \%$ of Jordanian listed firms are owned by managers. The average value of institutional ownership is $79.47 \%$. This finding is higher than the result of Al-Najjar (2008) who showed an average value of institutional ownership among Jordanian listed firms at $68 \%$. This means that the Jordanian firms have followed to the privatisation system that was launched during King Abdullah's reign in 2000 as an important step in economic reform system (ASE, 2009).

The results also show that the mean value of board independence was $66.24 \%$, whereas the minimum and maximum values were $25 \%$ and $94 \%$ respectively. This results show that the Jordanian listed firms have complied with the requirements of Corporate Governance Code (2009) which stated that the majority of board members should be independent. The result also shows that the average for board meeting is almost 6 meetings, whereas the minimum and maximum values were 2 and 14 meetings respectively. This result means that the Jordanian listed firms have complied with the requirements of Corporate Governance Code which stated that the board meeting should be at least 4 per year. This result indicates also that the boards of directors' meets dramatically and frequently which suggests that they 
addresses the important issues in their companies.

Table 1: Descriptive Statistics

\begin{tabular}{lllcll}
\hline \hline & $\mathbf{N}$ & \multicolumn{2}{c}{ Minimum } & $\begin{array}{l}\text { Std. } \\
\text { Deviation }\end{array}$ \\
\hline \hline MAN & 113 & .11 & .80 & .4870 & .16184 \\
INST & 113 & .40 & .93 & .7947 & .13865 \\
BIND & 113 & .25 & .94 & .6624 & .14375 \\
BMEE & 113 & 2.00 & 14.00 & 6.6372 & 2.52156 \\
T & & & & & \\
GC & 113 & -2.97 & 3.36 & .7319 & .94652 \\
\hline \hline
\end{tabular}

\subsection{Correlation Analysis}

Based on the Pearson Correlation Matrix, there is apositive coeefecient between going concern and each of managerial ownership, board independence and audit committee, while a negative coefficent with institutional ownership.

Managerial ownership has a positive coefficient with institutional ownership and board independence, while a negative relationship with board meeting. As for institutional ownership, this study finds a negative relationship between institutional ownership with both of board independence and board meeting. Regarding to the board independence, Table 2 shows that there is a negative relationship with board meeting.

Table 2: Pearson Correlation Coefficients

\begin{tabular}{llllll}
\hline \hline & MAN & INST & BIND & BMEET & GC \\
\hline \hline MANOW & 1 & & & & \\
INSTOW & .064 & 1 & & & \\
BIND & .071 & -.081 & 1 & & \\
BMEET & -.038 & -.061 & $-.201^{*}$ & 1 & \\
GC & .151 & -.139 & $.304^{* *}$ & .151 & 1 \\
\hline \hline
\end{tabular}

\subsection{Hypotheses Testing}

The data analyses of research model are based on regression analysis. Thus, before regression analyses were conducted, the assumptions of multiple regression analyses for research model were checked for all the variables. The assumptions are outliers, normality, linearity, multicollinearity, autocorrelation and Heteroscedasticity (Hair, Black, Babin \& Anderson, 
2010). The results show that there is no violation of these assumptions.

Four main hypotheses were developed andoffered in previous sections. Table 3 shows the results of multiple regression analysis. Table 3 illustrates that the research model is significant $(\mathrm{F}=5.502$, Sig $\mathrm{F}=0.00)$. The research model also explained $13.9 \%$ of the going concern variation (Adjusted $\mathrm{R}^{2}=.139$ ).

For the first hypothesis, Table 3 shows that the result is not consistent with our expectation; the direction of the relationship between managerial ownership and going concern evaluation is positive but not significant $(\mathrm{T}=1.618, \mathrm{P}=.109)$. The result is supported by the result of Mueller and Spitz (2002) who found that a managerial ownership has a positive influence on firm performance. Hence, the hypothesis H1 is not supported.

For the second hypothesis (H2), Table 3 shows that the direction of the relationship between institutional ownership and going concern is negative and not significant $(\mathrm{T}=-1.223, \mathrm{P}=.224)$. This result is not consistent with our expectation. Therefore, hypothesis $\mathrm{H} 2$ is not supported.

This study expected a positive association between board independence and going concern. However, the direction of the relationship between board independence and going concern is positive and significant $(\mathrm{T}=3.647, \mathrm{P}=.000)$ as shown in Table 3 . This result is consistent with our prediction. Thus, hypothesis $\mathrm{H} 3$ is accepted.

Regarding to therelationship between board meeting and going concern, Table 3 shows that there is a positive and significantrelationship between board meeting and going concern $(\mathrm{T}=$ $2.406, \mathrm{P}=.018$ ). This result is supported by the result of Greco (2011) who concluded that the board effectiveness is related to the frequency of board meetings. Accordingly, this study accepts hypothesis $\mathrm{H} 4$.

Table 3: OLS Regression Results

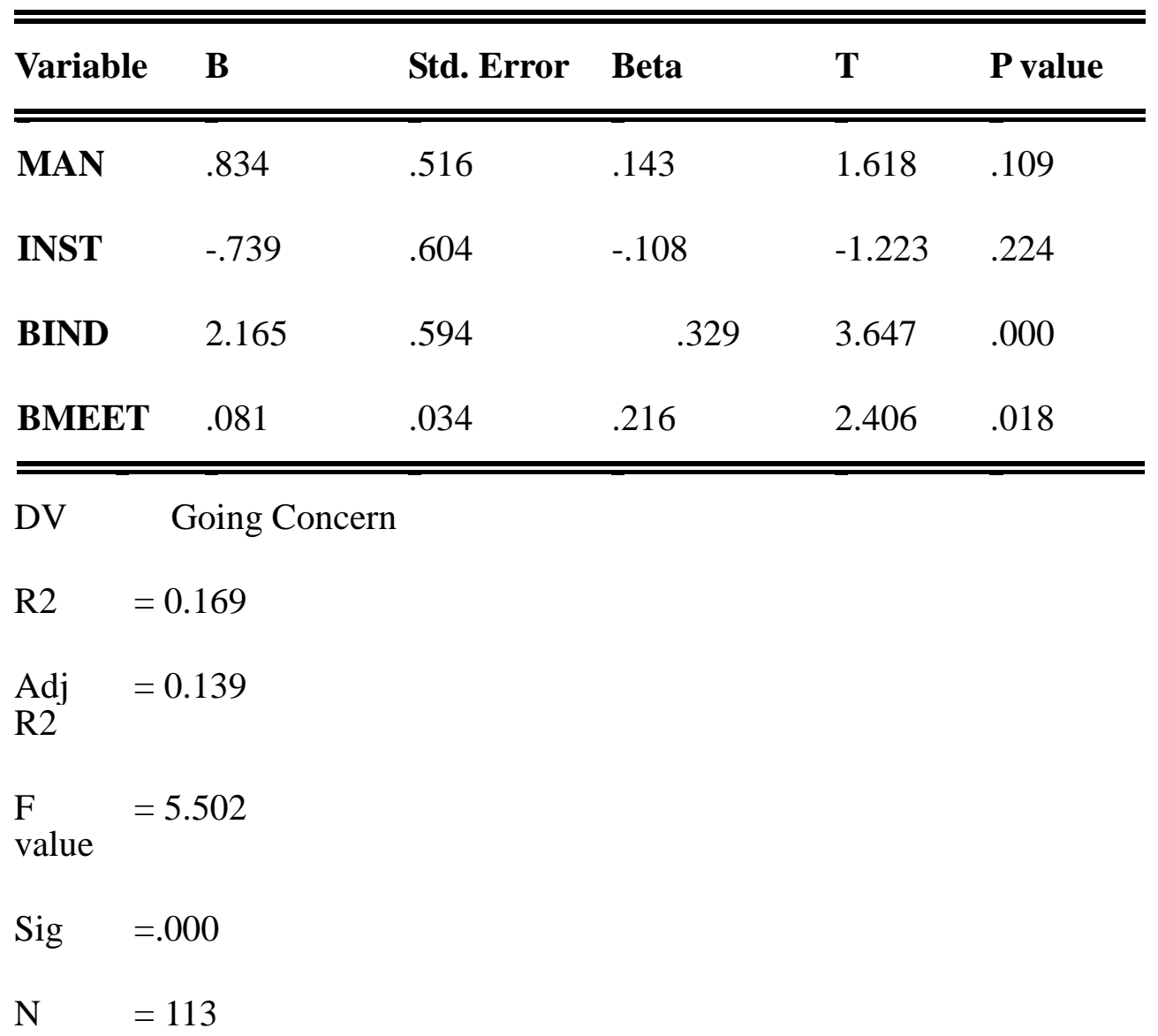




\section{Conclusion}

Through reviewing the literature of going concern, and to the best of researchers' knowledge, this study is one of the first studies that examined the relationship between corporate governance mechanisms and the going concern evaluation. Especially in emerging markets like Jordan. The contribution of this study can enhance our comprehension regarding the relevance of the agency theory in explaining the behaviour of the going concern evaluation within the context of the Jordanian business environment. It is also likely that the outcome of this study will reduce the literature gap between corporate governance and going concern evaluation. Further, this study also provides evidence of applying the same instrument in similar situations, especially in countries with emerging economies such as Jordan.

\section{References}

Abdullah, S. N. (2001). Characteristics of board of directors and audit committees among Malaysian listed companies in period leading to 1997 financial crisis. Akauntan Nasional, 14(10), 18-21.

Abed, S., Al-Attar, A., \& Suwaidan, M. (2012). Corporate Governance and Earnings Management: Jordanian Evidence. International Business Research, 5(1), p216.

agency problems between managers and shareholders. Journal of Financial and Quantitative Analysis 31, 377-396.

Agrawal, A. \& Knoeber, C., (1996). Firm performance and mechanisms to control

Ahmad, A. (2008). The Monitoring Role of Institutional Investors and Earnings Opacity, DBA Dissertation, Universiti Kebangsaan Malaysia, Bangi, Selangor.

Al-Akra, M., Jahangir Ali, M., \&Marashdeh, O. (2009). Development of accounting regulation in Jordan. The International Journal of Accounting, 44(2), 163-186.

Alexander, D., Veerle, D.V., \& Hubert, O. (2001). 'Corporate performance and board structure in Belgian companies', Long Range Planning, (34), 383-398.

Al-Fayoumi, N., Abuzayed, B., \& Alexander, D. (2010). Ownership structure and earnings management in emerging markets: the case of Jordan. International Research Journal of Finance and Economics, 38, 28-47.

Al-Najjar, B., \& Taylor, P. (2008). The relationship between capital structure and ownership structure: new evidence from Jordanian panel data. Managerial Finance, 34(12), 919-933.

Altman, E. I. (September, 1968). Financial Ratios, Discriminate Analysis and the Prediction of Corporate Bankruptcy. Journal of Finance, 23(4), 589-609.

ASE.(2009). Amman Stock Exchange. Retrieved from: http://www.ase.com.jo/pages.php?menu_id=119\&local_type=0\&local_id=0\&local_details=0

Beasley, M. S., Carcello, J. V., Hermanson, D. R., \& Lapides, P. D. (2000). Fraudulent financial reporting: Consideration of industry traits and corporate governance mechanisms. Accounting Horizons, 14 (4), 441-454.

Berle, A. A \& GC Means,(1932).". The modern corporation and private property.

Bhattacharya, P., \& Graham, M. (2007). Institutional ownership and firm performance: evidence from Finland. Available at SSRN 1000092.

Boone, A., Field, L., Karpoff, J., \& Rahega, C., (2006). The determinants of corporate board size: an empirical analysis. Working Paper, Vanderbilt University. 
Carcello, J. V., Hermanson, D. R., \& Neal, T. L. (2002). Disclosures in audit committee charters and reports. Accounting Horizons, 16(4), 291-304.

Chen, Y., Miller, J. R., Francis, J. A., \& Russell, G. L. (2011). Projected regime shift in Arctic cloud and water vapor feedbacks. Environmental Research Letters, 6(4), 044007.

Clay, D.G. (2001). Institutional ownership, CEO incentives and firm value, $\mathrm{PhD}$ dissertation, University of Chicago, Illinois, USA.

Davidson, W, Jiraporn, P., Kim, Y. S., \& Nemec, C. (2004). Earnings management following duality-creating successions: Ethno statistics, impression management, and agency theory. Academy of Management Journal, 47(2), 267-275.

Demsetz, H., \& Villalonga, B. (2001).Ownership structure and corporate performance. Journal of Corporate Finance, 7(3), 209-233.

Elloumi, F., \& Gueyie, J. (2001). Financial distress and corporate governance: an empirical analysis, Corporate Governance, 1 (1), 15-23.

Fama, E. F., \& Jensen, M. C. (1983). Separation of ownership and control .Journal of law and economics, 301-325.

Fosberg, R.H. (1998). Outside directors and managerial monitoring. Akron Business and Economic Review, 20(2) 24-32.

Gilson, R.J., \& Kraakman, R. (1991). Reinventing the outside director: an agenda for institutional investors. Stamford Law Review, 43, 863-906.

Greco, G. (2011). Determinants of board and audit committee meeting frequency: Evidence from Italian companies. Managerial Auditing Journal, 26(3), 208-229.

Gul, M., Atalay, M., \& Hanninen, O. (2003).Endurance training and glutathione-dependent antioxidant defence mechanism in heart of the diabetic rats.Journal of Sports Science and Medicine, 2, 52-61.

Habbash, M. (2010). The effectiveness of corporate governance and external audit on constraining earnings management practice in the UK(Doctoral dissertation, Durham University).

Hair, J. F., Black, Babin, Anderson, \& Tatham, R. L. RE (2010): Multivariate Data Analysis. A Global Perspective.

Hart, O. (1995). Corporate governance: some theory and implications. The economic journal. 678-689.

Iskandar, T. M., Rahmat, M. M., Noor, N. M., \& Saleh, N. M (2011). Corporate governance and going concern problems: evidence from Malaysia. International Journal of Corporate Governance, 2(2), 119-139.

Jensen, Michael C., \& Meckling, William H. (1976). Theory of the firm: managerial behaviour, agency costs and ownership structure. Journal of Financial Economics 3, no. 4 (October): 305-60.

LaFond, R., \& Watts, R.L., (2006). The information role of conservative financial statements.Working Paper, Massachusetts Institute of Technology.

Leftwich, R., Watts, R., Zimmerman, J., (1981). Voluntary corporate disclosure: the case for interim reporting. Journal of Accounting Research 19, 50-77.

Malaysian Institute of Accountants (MIA) (2008) ISA 570 Going Concern, Approved Standards on Auditing, MIA, Kuala Lumpur.

Ministry of Industry and Trade. (2012). Companies' Controlling Department. retrieved from: 
http://www.ccd.gov.jo/

Mueller, E., \& Spitz, A. (2002). Managerial ownership and firm performance in German small and medium-sized enterprises. Centre for Economic Performance, London School of Economics and Political Science.

Parker, S., Peters, G. F., \& Turetsky, H. F. (2005).Corporate governance factors and auditor going concern assessments.Review of Accounting and Finance, 4(3), 5-29.

Parng, Y. J. M., \& Fu, C. J. (2011). Detecting firms with going-concern risk based on the industry affiliation, corporate governance characteristics, and financial performance. African Journal of Business Management, 5(22), 9249-9261.

Perry, T., \& Shivdasani, A. (2005). Do Boards Affect Performance? Evidence from Corporate Restructuring. The Journal of Business, 78 (4), 1403-1432.

Thomsen, F., Betke, K., Schultz-von Glahn, M., \& Piper, W. (2006). Noise during offshore wind turbine construction and its effects on harbour porpoises (Phocoenaphocoena). Paper presented at the $20^{\text {th }}$ Annual Conference of the European Cetacean Society, Gdynia, Poland, 2-7 April.

Uzun, H., Szewczyk, S. H., \&Varma, R. (2004). Board composition and corporate fraud.Financial Analysts Journal, 33-43.

Vafeas, N. (1999). Board meeting frequency and firm performance. Journal of Financial Economics, 53(1), 113-142.

Xie, B., Davidson, W. N., \& DaDalt, P. J. (2003). Earnings management and corporate governance: the role of the board and the audit committee. Journal of Corporate Finance, $9(3), 295-316$. 